\title{
LIV. On the fusion and appearance of refined and unrefined copper
}

\section{David Mushet Esq.}

To cite this article: David Mushet Esq. (1835) LIV. On the fusion and appearance of refined and unrefined copper, Philosophical Magazine Series 3, 6:35, 324-327, DOI: $10.1080 / 14786443508648611$

To link to this article: http://dx.doi.org/10.1080/14786443508648611

册 Published online: 01 Jun 2009.

Submit your article to this journal

Џ Article views: 2

Q View related articles $₫$ 
Nevertheless, the inquiry as to the existence of local variations in the quantity of bromine, and as to the cause of such variations, is one worth prosecuting; and to those who are favourably circumstanced for such investigations I may venture to recommend the above indirect method of calculating the relative proportions of two intermixed and similar ingredients, which we owe to M. Gay-Lussac; and I do so with greater confidence, now that I find its application to the case in question sanctioned by the adoption of so experienced a chemist as Dr. Ure. I remain, Gentlemen, yours, \&c.

Oxford, March 27, 1835.

Charles Daubeny.

LIV. On the Fusion and Appearance of refined and unrefined Copper. By David Mushet, Esq.

\section{To the Editors of the Philosophical Magazine and Journal.}

Gentlemen,

A $S$ you thought my observations on the alloys of iron and A copper deserving of insertion in your Magazine (for $\mathrm{Fe}-$ bruary last), perhaps you will allow me to forward you a few extracts from experiments made some years ago, with a view to ascertain what effect would be produced upon the strength and malleability of copper by retaining to a certain extent the alloy (chiefly tin) which is found in rough copper and which it is the purpose of the copper-refinery to discharge. In the first place, I obtained a quantity of shotted rough copper, made from the furnace in which the copper, though alloyed with other matters, first appears in its metallic form. These shots were light and flaky, hard when struck, but at the same time partially ductile. A quantity of pure shotted copper made from the refinery, and having the form of flattened spheroids and much denser than the other, was procured at the same time for the purpose of these experiments.

Exp. No. 1. A quantity of rough copper was fused in a black-lead crucible with nearly an equal bulk of charcoal, and poured into an open iron mould. The bar or ingot thus made was $\frac{3}{4}$ ths of an inch thick, and when cold and broken, was found to have crystallized in converging striæ perpendicular to the upper and lower surfaces, and declining towards the outer edges of the bar. The grain was of a pale colour inclining to gray, indicating the presence of tin.

Exp. No. 2. Three bars procured in this way were melted together in a black-lead crucible without charcoal, and poured into a mould just at the moment when the melted copper put 
on a creamy appearance. When cold, the surface of the ingot thus obtained was less coppery-metallic than the surface of the ingot in the first experiment, where charcoal was used, from which it may be inferred that, owing to the absence of charcoal, a certain degree of refinement had taken place. The fracture possessed more of the red grain of good copper; the strix were less distinct and less crystalline; and the surface instead of being convex, as in the first experiment, was concave.

Exp. No. 3. Some of the pure shotted copper was fused in a black-lead crucible with an equal bulk of charcoal, and the resulting ingot presented a more clean and perfect mass of copper than the ingots obtained in Experiments No. 1 and No.2. The fracture presented a series of brilliant striæ arranged from surface to surface, breaking off easily in the direction of the perpendicular fibre; a structure which seems wholly incompatible with extension and malleability.

Exp. No. 4. Some of the same pure copper melted similarly, but not poured into the mould until it had nearly lost its fluidity, formed an ingot less striated or crystallized than any of the former, with more of that minute deep orange-coloured grain which is peculiar to pure and malleable copper. From the results of this experiment, and of No. 2, it would seem that when copper is poured into the mould at as low a temperature as is consistent with perfect fluidity, the fracture is less crystallized, and the colour approximates to that ruby grain which indicates the malleable state of copper.

Four bars, one from each of the foregoing experiments, were imbedded in burnt lime, shut up from the access of air, and exposed in crucibles to the same temperature. The pure copper bars (Nos. 3. and 4.) were on the surface considerably oxidated, but those made from the rough copper (Nos. 1 . and 2.) were entirely free from oxide; and from this it may be inferred that the alloy (principally tin) which still remained in the copper prevented waste or oxidation. The bar from Experiment No. 1. was not cut, but that from Experiment No. 2. retained about the same quantity of grained strix as before the cementation; though, compared with a fracture of the same copper that had not been cemented, the grain was redder, the colour more brilliant, and the metal more ductile. The bar from Experiment No. 3. was covered with a thin coating of crystallized oxide exceedingly soft; the stria were more enlarged and adhesive, so that the copper, in cutting, tore out in flakes, which separately were soft and ductile. The bar from No. 4. when examined and compared with an uncemented one was more open in the grain, redder, and more brilliant; 
but the quantity or depth of grain was nowise altered, although the metal cut softer, and was covered with a thin crust of shining oxide. From these details it may be presumed that cementation opens the grain, renders the bar less dense, but does not change the peculiar form of the arrangement. In each case the copper after cementation was softer, a change which seems favourable to rolling cold. The impure or rough copper appears to be alloyed with another metal (no doubt tin), which prevents that oxidation which pure copper in the same circumstances would undergo.

Besides the above, several bars were made from the rough copper by a slower fusion, and with a longer exposure to the charcoal; and it was observable that the longer the exposure, and the slower the fusion, the more yellow and refined was the copper in the bar.

Some of the bars produced in the course of these experiments were attempted to be rolled; but the success was various. Of those made from the pure copper, some rolled better and others worse than any made from the rough copper: one or two bars of the latter were equally malleable with the former; but none rolled well either hot or cold. In those bars in which the striated arrangement was most perfect, the capacity for rolling was least, and those in which the minute granular fracture prevailed, generally rolled the best. It certainly does appear that this tendency to crystallize, so destructive to malleability, is peculiar to English copper made from the crucible. There are occasions, no doubt, when, the proper temperature being hit upon, the bar would roll; but these occasions are so rare and uncertain that English copper made in this manner could not be relied upon in the manipulations connected with manufactures. There is no question that the arts in this country suffer from the peculiarity of English copper. For in consequence of it the malleabilization of that metal is necessarily confined to the original process of refining practised on the great scale by the copper smelters. It is very different with Swedish and Kussian copper, which I have seen melted in considerable quantities in large crucibles, cast into cakes or thick sheets, and afterwards rolled into boiler plate and thin sheet copper. This subject requires and deserves a scrutinous examination, with a view to discover the cause of the uniform tendency of English copper to crystallize; and that cause may, perhaps, be found in the process employed in this country for the smelting of copper ores, a process which, however œconomical and well calculated to overcome quantity, has never yet produced pure copper.

Should these remarks obtain a place in your Magazine, 
I will, when at leisure, send you some details of experiments made with rough and pure copper exposed to the action of muriatic acid. I am, Sir, yours, \&c.

David Mushet.

LV. On Water as a Constituent of Salts. In the Case of Sulphates. By Thomas Graham, F.R.S.E., Andersonian Professor of Chemistry and Vice-President of the Philosophical Society of Glasgow.*

IT may be useful to distinguish some of the functions which water is already admitted to discharge in the constitution of hydrated salts.

Every salt of ammonia with an oxygen acid contains an atom of water, and cannot exist without it. The state of combination of the water is peculiar, and has been represented by supposing that the elements of ammonia unite with the hydrogen of the water, and form a new compound radical, to which the name ammonium is given, while the oxygen of the water unites with this radical, and produces oxide of ammonium. Hence nitrate of ammonia, in which there exist the elements of one atom of nitric acid, of ammonia, and of water, is viewed as anhydrous nitrate of the oxide of ammonium, and corresponds with nitre or the nitrate of the oxide of potassium. But it is not the object of this paper to discuss particularly the state of water in the ammoniacal salts.

We have it often in the crystals of salts, united by a feeble affinity, and known under the name of water of crystallization. The number of atoms of water with which some salts unite, in crystallizing from a state of solution, is affected by temperature, and other slight causes. This water is commonly viewed as a constituent of salts which is not essential, owing to the facility with which it may in general be expelled by heat, and also to the circumstance that many salts usually hydrated, are likewise capable of existing in a crystalline state without water.

In the hydrates of the caustic alkalies and of the earths, water is retained by a strong affinity, and is generally supposed to be united, like an acid, to the alkali or earth. In such hydrates, water discharges an acid function.

In the case of hydrates of the acids, the portion of water which is found to be inseparable by heat, or to be very strongly retained, has generally been presumed to be in the place of a base to the acid, although little attention has been

* From the Transactions of the Royal Society of Edinburgh, vol. xiii. Part I. recently published: revised by the Author. 